\title{
THE CREATION STORY OF KASHMIRI PEOPLE: THE RIGHT TO SELF-DETERMINATION
}

\author{
Fozia N Lone*
}

\begin{abstract}
If a group wishes to exercise the right to self-determination, they need to establish that they are a "people" within the international law definition, thereby triggering the ability to claim this right. Thus, the definition of the term "people" is the key in cases of self-determination and always posits difficult challenges. This article aims to determine whether the "Kashmiri people" could be identified as a group that fits within the contemporary nonexhaustive definition of people. Having ascended from the level of subjects of an autocratic rule to victims of human rights violations, are Kashmiris now in a position to exercise a right to self-determination?
\end{abstract}

\section{INTRODUCTION}

The territory of Kashmir, located in the foothills of Himalayan mountain range in South Asia, was until 1947 under the paramountcy of the British Crown as the Princely State of Jammu and Kashmir. The British decolonisation of the Indian subcontinent became instrumental in creating a disorder that pushed Kashmir into the throes of an unending war. Britain decided to grant independence to British India; however, they did not adequately define the relationship between the Princely States and the new Dominions, i.e. India and Pakistan. ${ }^{1}$ Once the British paramountcy was withdrawn in 1947, the territory of Princely State of Kashmir became a continuous source of tension between India and Pakistan. This territory ignited four wars between these newly formed nations and has been described as the "most dangerous place in the world" by the former US President Bill

\footnotetext{
* Assistant Professor, City University of Hong Kong \& Honorary Research Assistant, University of Aberdeen.

${ }^{1}$ H Hodson The Great Divide - Britain India Pakistan (London: Hutchinson, 1969).
} 


\section{THE CREATION STORY OF KASHMIRI PEOPLE: THE RIGHT TO SELF-DETERMINATION}

Clinton. $^{2}$ Today India and Pakistan are nuclear countries and a fifth war between them could make Kashmir a battlefield for possible nuclear warfare. ${ }^{3}$

Over the years the wars left the territory of Kashmir divided between India, Pakistan and China. In the 1962 war with India, China occupied the northern Ladakh region called Aksai Chin, which is rich in mineral resources and has an area of 14,500 square miles. ${ }^{4}$ The 15 million strong people of Kashmir, who share a common heritage and culture over the centuries, are now trapped between the de facto borders. Over the last 61 years Kashmiri people found themselves wedged between India and Pakistan and governed by unrepresentative regimes. ${ }^{5}$ The bilateral diplomatic peace process between India and Pakistan produced no results since 1947. Although the UN Security Council resolutions urged the two countries to hold a plebiscite to determine the will of the people, ${ }^{6}$ these resolutions are still not observed. Since 1989 the people of Indian Administered Kashmir (IAK) were victims of massive violations ${ }^{7}$ of individual human rights and after an armed struggle they started claiming their right to self-determination.

Over the years the debate over the right to self-determination, particularly outside the decolonisation, has been received with little or no interest by the international community. The concept of independence through secession is seen as a "bad recipe" ${ }^{8}$ and an assault on the territorial integrity ${ }^{9}$ of the States;

2 J Marcus “Analysis: The World's Most Dangerous Place?” BBC News, March $23^{\text {rd }}$ 2000 [Available at <http://news.bbc.co.uk/1/hi/world/south_asia/687021.stm> Accessed on December $\left.11^{\text {th }} 2007\right]$.

${ }^{3} \mathrm{~K}$ Brew “The Re-Emergence of Nuclear Weapons as 'The Coin of the Realm' and "The Return of Nuclear Brinkmanship in South Asia: The Nuclear Sword of Damocles still Hangs by a Thread” (2005) 52 Naval L Rev 177.

4 A Mountjoy (ed) Guide to Places of the World (Reader's Digest Association Limited, 1987) p 19.

${ }^{5}$ For rigging of elections in IAK see A Santos Military Intervention and Secession in South Asia (Praeger, Security International, 2007) pp 70-71. Azad Kashmir or Pakistani Administered Kashmir may be seen as an autonomous part under Pakistan but in practice, elections are not free and fair (July 2006). See K Adeney "Democracy and Federalism in Pakistan” in B He, B. Galligan \& T Inoguchi (eds) Federalism in Asia (London: Edward Elgar Publishing, 2007) p 101 at p103.

${ }^{6}$ SC Res. 47 (21 April 1948); UNCIP SCR 13 August 1948; and UNCIP SCR 5 January 1949.

${ }^{7}$ During the Clinton Administration both the House of Representatives and Senate deplored the use of violence and torture by Indian security forces against civilians. See House of Representatives Resolution, H Res. 87 of February $22^{\text {nd }} 1991$ \& Senate Resolution S Res. 91 of March $21^{\text {st }} 1991$.

${ }^{8}$ Ü Enginsoy “Greece Sees Kosovo Independence as bad recipe for region”, Turkish Daily News, February $15^{\text {th }} 2008$ [Available at:

$<$ http://www.turkishdailynews.com.tr/article.php?enewsid=96422> Accessed on December $\left.18^{\text {th }} 2008\right]$. 
therefore it is not accepted. For this reason Kosovo's declaration of unilateral independence left the European Union split as to whether they should recognise Kosovo or not. ${ }^{10}$ It sent shock waves around the world especially to countries such as Cyprus, Greece, Romania, Bulgaria, Slovakia, Russia, India and China, who expressed anxiety about the signal that Kosovo's recognition might send to the separatists in their countries. ${ }^{11}$ For this reason the definition of "people", for the purposes of self-determination, remains controversial.

On the other hand there is no disagreement that "each nation has a unique tune to sound in the symphony of human culture; each nation is an indispensable and irreplaceable player in the orchestra of humanity."12 The world is a collage of nations and each one is inhabited by a number of disparate populations and groups. All of them have different values of civilisation and tend to define themselves differently as a unit, group, people and nation. The most complex predicament of self-determination is therefore the identification of the units, ie the peoples who are entitled to exercise this right. However, the whole issue is complicated by the fact that today all men and women are more acutely aware of the unit to which they belong and more forcibly express their needs and demands as a group. ${ }^{13}$ The diverse groups and populations have described themselves differently depending on their choice and circumstances. Some groups of indigenous people and minorities have claimed to be the people for the purposes of the right to selfdetermination, which although has increased the ambit of this principle has nevertheless made it contentious.

Regardless of these controversies, this discourse after critically evaluating the history and culture of Kashmir including contemporary non-exhaustive definitions of people within the international law for the purposes of the right to self-determination, would consider whether the people of Kashmir correspond to the current description of people.

${ }^{9} \mathrm{P}$ Groarke Dividing the State-Legitimacy, Secession and the Doctrine of Oppression (USA: Ashgate, 2004) p 3.

${ }^{10} \mathrm{~S}$ Castle "Behind the scenes, EU splits over Kosovo" Herald Tribune February $18^{\text {th }}$ 2008 [Available at <http://www.iht.com/articles/2008/02/18/europe/diplo.php>. Accessed December $18^{\text {th }}$ 2008].

${ }^{11}$ Recognition for new Kosovo grows BBC News 24, February $18^{\text {th }} 2008$. Available at $<$ http://news.bbc.co.uk/1/hi/world/europe/7251359.stm\#map>.

12 I Claude National Minorities: An International Problem (Cambridge: Harvard University Press, 1995) p 85.

${ }^{13}$ H Schoenberg "Limits of Self-Determination” (1976) 6 Israel Yearbook on Human Rights 91. 


\section{HISTORICAL AND CULTURAL BACKGROUND TO THE KASHMIR CRISIS}

\section{(a) Roots of Conflict}

The organic population of Kashmir has a lineage that dates back to thousands of years of written history. From the ancient times Kashmir was an attraction for various invaders who found their doorway through passes in the mountains ranges of the Himalayas, Pamirs and Hindu Kush. There were whirlwind incursions by Zulfi Khan from Mongolia, RinChin from Tibet and Alexander the Great from Macedonia in Greece in 326 BC. ${ }^{14}$ The Princely State of Kashmir was created as an autonomous political entity in 1846 when Dogra General Gulab Singh, the local chieftain of Jammu State, helped the British to win the Second Sikh War. The Sikh ruler, who was unable to pay the war indemnity, was forced to forfeit the territory of Kashmir to the British instead. The British did not adopt the territory for long, and under the Treaty of Amritsar $1846^{15}$ (TOA), sold Kashmir including Gilgit to Gulab Singh ${ }^{16}$ for the nominal sum of 75 Lakh Rupees ${ }^{17}$ (approximately $£ 100,000$ ).

By the TOA 1846, Maharaja Gulab Singh acknowledged the supremacy of the British Government and had to pay annually a nominal sum of money to the British Government. ${ }^{18}$ This treaty was unique because it provided the Dogra rulers full internal autonomy. ${ }^{19}$ The State of J\&K took its final shape only after the Dogras united it together with the adjacent conquered territories in various periods. ${ }^{20}$ The final territory of the Princely State of Kashmir included the region of Jammu, Kashmir, Ladakh, Gilgit and Baltistan. Politically this was the beginning of a union of diverse ethnic communities speaking a variety of languages such as Kashmiri, Dogri, Gojari, Punjabi, Pahari, Bodhi, Balti, Burushashki, Pashto, Tibeto-Burman, Kohistani,

14 J Korbel Danger in Kashmir (Princeton: University Press, 1954) p 9.

15 The Treaty of Amritsar concluded on March $16^{\text {th }} 1846$ (No. CXXXI).

${ }^{16}$ M Rai Hindu Rulers, Muslim Subjects: Islam, Rights and the History of Kashmir (London: Hurst \& Company, 2004) pp 129-130.

${ }_{17}$ Art 3 of Treaty of Amritsar March $16^{\text {th }} 1846$.

$18 \mathrm{~S}$ Ali and J Rehman Indigenous Peoples and Ethnic Minorities of Pakistan Constitutional and Legal Perspectives (Curzon, 2001) pp 117-119.

${ }^{19} \mathrm{C}$ Aitchison A Collection of Treaties, Engagements and Sanads Relating to India and Neighbouring Countries (Calcutta: Foreign Office Press, Vol 11, 1909) pp 165166.

${ }^{20}$ Maharaja Gulab Singh started his rule by conquering the neighbouring territories of Ladakh in the east in 1834 and conquered Baltistan (Skardu) in 1840. Gilgit Agency (Gilgit) in the Northwest was recaptured by Maharaja Ranbir Singh (Gulab Singh's son) in 1860. Finally in 1936 Maharaja Hari Singh also controlled Jagir (fief) of Poonch. 
Khowar, Urdu and Shina/Dardi. ${ }^{21}$ The Dogra dynasty ruled J\&K for a century as totalitarian autocrats unleashing a tyrannical rule over the people. ${ }^{22}$ In 1931, unlike any other Princely State, people in Kashmir became aware of their political rights and started a united rebellion against Dogra repression. This political awareness is seen as the first claim for the right to selfdetermination in the history of Kashmir. ${ }^{23}$

The 1947 fall was the most poignant defining moments in the history of the subcontinent, which coincided with the end of British Empire ${ }^{24}$ and creation of two independent States on August $15^{\text {th }} 1947$. The two new Dominions of India and Pakistan were carved out of British India on the basis of Two-Nation Theory. ${ }^{25}$ The mainstay guide in the theory asserts a separate State of Pakistan for Muslims to avoid their likely domination by the majority Hindus of India. The Princely India consisted of almost 584 states scattered across the British Indian Empire. ${ }^{26}$ Kashmir was a Muslim majority Princely State with an 80 percent Muslim and 20 percent minority population, which included Hindus, Sikhs and Buddhists. ${ }^{27}$ On May $12^{\text {th }} 1946$, the British Cabinet Mission Memorandum was passed which ended the paramountcy and declared that all Princes were free to accede or remain independent. ${ }^{28}$ At that time the Maharaja of Kashmir Hari Singh decided to remain independent and did not accede to British India. ${ }^{29}$ In this regard it is argued that British India recognised Kashmir as a separate territory by conferring on its inhabitants the choice to remain independent, and hence considered Kashmiris to be people within the pre-1947 borders.

Threatened by the Poonch revolt in 1947 and tribal invasion from North West Frontier Province (Pakistan), Hindu Maharaja Hari Singh sought assistance from India, which was perhaps a natural choice for him. India,

\footnotetext{
${ }^{21}$ Above $\mathrm{n} 18$, at 118 .

${ }^{22}$ W Thomson A Memoir of William Jackson Elmslie (London: James Nisbet \& Co, 3rd edn, 1881) pp 76 - 77.

${ }^{23}$ H Sender The Kashmiri Pandits - A Study of Cultural Choice in North India (New Delhi: Oxford University Press, 1988) p 4.

${ }^{24}$ M Siraj Kashmir: Desolation or Peace (London: Minerva Press, 1997) p 37.

${ }^{25}$ At the Lahore session of the Muslim League in March 1940, Mohammad Ali Jinnah introduced the resolution, which included the demand of Pakistan although the term was itself avoided. It was in this resolution Jinnah asserted that the Muslims of India are a nation by any definition of the term and came to be called "Two Nations Theory".

${ }^{26}$ B Ramusack The Cambridge History of India - the Indian Princes and their States (Cambridge: University of Cambridge, 2004) p 2.

${ }^{27}$ Birdwood India and Pakistan (New York: Frederick A Praeger, 1954) p 302.

${ }^{28}$ Cabinet Mission Memorandum Command Paper 6855 (May 12, 1946).

${ }^{29}$ Maharaja Hari Singh was the last Dogra ruler. See, W Baker Kashmir, Happy Valley, Valley of Death (Defenders Publication, 1994) p 21.
} 


\section{THE CREATION STORY OF KASHMIRI PEOPLE: THE RIGHT TO SELF-DETERMINATION}

however, refused help without Maharaja's accession to India. Maharaja Hari Singh signed the Instrument of Accession (IOA) with India on October $26^{\text {th }}$ 1947 without the wishes of the people of Kashmir who happened to be a Muslim majority. ${ }^{30}$ The IOA was however conditional to the plebiscite and limited to defence, communications and foreign affairs. ${ }^{31}$ It was followed by war between India and Pakistan on October $27^{\text {th }} 1947 .{ }^{32}$

In 1948 India brought the Kashmir question to the attention of the Security Council (SC) pursuant to Art 35 under the UN Charter (UNC). After international deliberations, SC Resolution (SCR) 47 of April $21^{\text {st }} 1948$ was passed advocating a two tier solution of demilitarisation and a plebiscite for deciding the status of the territory of Kashmir. SC noted that:

The question of accession of Jammu and Kashmir to India or Pakistan should be decided through the democratic method of a free and impartial plebiscite. ${ }^{33}$

The subsequent SCRs reiterated the demilitarisation and plebiscite provision of Resolution $47 ;^{34}$ however, they were not abided by India or Pakistan. In 1949, despite the disagreement between India and Pakistan as to demilitarisation, the UN Commission obtained a ceasefire agreement between them. On July $27^{\text {th }} 1949$ India and Pakistan reached an agreement on the demarcation of the ceasefire line, ${ }^{35}$ which created a de facto border. The UNbrokered ceasefire divided the Princely State of Jammu and Kashmir into Indian Administered Kashmir (IAK) consisting of Ladakh, Jammu and Kashmir Valley; and Pakistani Administered Kashmir (PAK) comprising of Mirpur, Muzaffarabad, Gilgit and Baltistan.

The UN acted by the deployment of the first UN Military Observer Group in India and Pakistan (UNMOGIP) to Kashmir to supervise the ceasefire line in the State, which still remains functional. The cessation of hostilities did not remain operative for long and India and Pakistan found themselves locked in wars in 1965, 1971 and 1999. On July $2^{\text {nd }} 1972$, after the Bangladesh war, the

30 A Singh "The Right of Self-Determination: Is East Timor a Viable Model for Kashmir?” (2001) 8 No 3 Human Rights Brief 9.

${ }^{31}$ V Schofield Kashmir in the Crossfire (New Delhi: Viva Books Private Ltd, 1997) p 148.

32 M Siraj Towards Peace in Jammu, Kashmir and Ladakh (India: Manas Publications, 2003) pp 45 - 46.

${ }^{33}$ Above n 6, para [B (7)].

${ }^{34}$ UNCIP Resolutions August $13^{\text {th }} 1948$ \& January $5^{\text {th }} 1949$; SCR 91 (March 30 ${ }^{\text {th }}$ 1951); 96 (November 10 $10^{\text {th }} 1951$ ); 98 (December 23 $\left.{ }^{\text {rd }} 1952\right) ; 122$ ( 1957); and 126 (December $\left.2^{\text {nd }} 1957\right)$.

35 Agreement Regarding the Establishment of Cease-Fire Line in the State of Jammu and Kashmir, July 27 $7^{\text {th }} 1949$, 81 UNTS 273. 
two countries signed the Simla Agreement, ${ }^{36}$ which renamed the ceasefire line as Line of Control (LOC). The Simla Agreement could be seen as a landmark on bilateral relations between these two nations who decided "to settle their differences by peaceful means through bilateral negotiations or by any other peaceful means mutually agreed upon between them". ${ }^{37}$ India after this agreement took the position that the Kashmir question is to be solved by "bilateral negotiations and rejected the UN involvement". ${ }^{38}$ However, it continues to remain the central plank of Pakistan's policy to decide the Kashmir issue through UN involvement. ${ }^{39}$ In this context it is important to mention firstly that the Kashmiri people were not a party to this agreement and for this reason it is arguable that it cannot dispossess them of the right to plebiscite granted by SC. Secondly, the SCRs take precedence over the Simla Agreement, particularly because India and Pakistan have a disagreement over the resolution of the Kashmir issue. In this background Article 103 of UNC makes it clear that:

"In the event of a conflict between the obligations of the Members of the United Nations under the present Charter and their obligations under any other international agreement, their obligations under the present Charter shall prevail.”

For these reasons and the subsequent Kargil War (1999), unaided bilateralism created by the Simla Agreement remains a less significant proposition to decide the future of the territory of Kashmir.

Since the 1950s, India gradually backed out of its commitment to SCRs and began its campaign to constitutionally incorporate entire territory of the Princely State of Jammu and Kashmir into its union. India nominated the State Constituent Assembly for Jammu and Kashmir for the purpose of legalising the contested accession by conducting elections that are known to be rigged. ${ }^{40}$ This assembly consisted of local political party "All Jammu and Kashmir National Conference" (NC) that won an election in which the nomination papers of all other candidates except the NC members were

\footnotetext{
36 The Simla Agreement was signed between Zulfikar Ali Bhutto (then President of Islamic Republic of Pakistan) and Indira Gandhi (then Prime Minister of Republic of India) in Simla on July $2^{\text {nd }} 1972$.

${ }^{37}$ The Simla Agreement 1972 at para [1(ii)].

${ }^{38}$ C Snedden "Would a Plebiscite have resolved the Kashmir Dispute?" (April 2005) Vol. XXVIII No. 1 Journal of South Asian Studies, pp 65-86 at p 64.

${ }^{39}$ Above n 31, at p 289.

40 B Singh Autonomy or Secession Jammu and Kashmir (India: Har-Anand Publications Pvt Ltd, 2001) p 12.
} 


\section{THE CREATION STORY OF KASHMIRI PEOPLE: THE RIGHT TO SELF-DETERMINATION}

rejected, hence "winning unopposed." ${ }^{41}$ It is this assembly that was given the responsibility to draft the new Constitution of Kashmir, which came into force in 1957, determining Kashmir as an integral part of India. ${ }^{42}$ It is submitted that both the State Constituent Assembly as well as the new Constitution of Kashmir was formed in violation of the SCR 91 (1951) and 122 (1957), which rejected any action of this assembly to determine the future shape and affiliation of the entire state of Jammu and Kashmir. ${ }^{43}$ Despite these SCRs today, IAK is tied to the Union of India through Art 370 of the Indian Constitution, which is supposed to gives Kashmir a special status. This article affirms that Indian laws would be applied in Jammu and Kashmir in concurrence with the state government's endorsement. ${ }^{44}$ However, India soon forgot this commitment and began to transport unilaterally central laws into the state. ${ }^{45}$ Although the autonomy of Kashmir is protected by the terms of the accession deed albeit, this status has been superseded and not respected by India. ${ }^{46}$ Since 1947, the people in IAK have lived under the unrepresentative governments and elections are rigged and people are forced to vote under the shadow of the gun. ${ }^{47}$ This practice continues unabated, which is clear by the 2008 elections that were marred by violence, boycott and curfews. ${ }^{48}$

Pakistan rules Gilgit and Baltistan from Islamabad through the Northern Areas Council and its political relations with Azad Kashmir are controlled by the Karachi Agreement of April $28^{\text {th }} 1949$. The people in the Gilgit-Baltistan area are unsettled and believe that their political future is linked with Jammu and Kashmir State. ${ }^{49}$ The northern areas are economically backward despite the fact that it has vast natural resources of timber and a potential for tourism. Their human rights are compromised including opportunities for education

${ }^{41}$ Ibid, p 40.

42 FO 371/129777: DY1041/46 (E): Outward Telegram from Commonwealth Relations Office to UK High Commissioner in Canada, Australia, India and Pakistan February $16^{\text {th }} 1957$ [The National Archives, London].

${ }^{43}$ SCR 91(1951) Preamble; and SCR 1221957 Para [1].

${ }^{44}$ Abhyankar, "Constitution of India" in Flanz (ed) Constitutions of the Countries of the World (New York: Oceana Publications, 1997) pp 147 -148.

${ }^{45}$ S Bose Kashmir (Harvard University Press, 2003) pp 45-46.

${ }^{46} \mathrm{R}$ Bruce McColm Freedom in the World (New York: Freedom House, 1993) p 570.

${ }^{47}$ S Ganguly The Crisis in Kashmir: Portents of War, Hopes of Peace (Cambridge: Cambridge University Press, 1997) p 84.

48 M Ahmad "Protesters, security forces clash during Kashmir elections" CNN.com/Asia November $23^{\text {rd }} 2008$. Available at

$<$ http://edition.cnn.com/2008/WORLD/asiapcf/11/23/kashmir.elections/> Accessed January $3^{\text {rd }} 2009$.

${ }^{49}$ In this regard Balawaristan National Front, a political party was formed on July $30^{\text {th }}$ 1992, which put forth the illegal occupation of the area at the hands of Pakistan. See $<$ www.balawaristan.net/> accessed on December $30^{\text {th }} 2008$. 
resulting in the literacy rate of just 14 percent for men and 3.5 percent for women. $^{50}$

In IAK from 1989 the political uprising against the Indian occupation resulted in the open confrontation between the insurgent groups and the Indian army. There was a popular demand for the right to self-determination a right ostensibly denied to the people ever since the SC, India and Pakistan promised them a plebiscite in 1947. In the counter-insurgency process, India deployed $700,000^{51}$ troops to Kashmir, which is the largest soldiers-to-civilian ratio in any conflict of the world. In proactive anti-insurgency operations the Indian Army perpetrated many human rights violations such as extra-judicial killings, custodial killings, disappearances, rape and torture. ${ }^{52}$ Over the years thousands of Kashmiri people have been arrested in search operations and many homes, schools and institutions were gutted. Approximately 8-10,000 people have disappeared after arrest and more than $80,000^{53}$ people have been killed also creating 2.05 million displaced people. ${ }^{54}$ All of these human rights violations are well documented by the Human Rights Watch, ${ }^{55}$ Amnesty International, ${ }^{56}$ Physicians for Human Rights, ${ }^{57}$ and indigenous human rights organisations such as the Coalition for Civil Societies. ${ }^{58}$ The US State Department Country Report on Human Rights Practices for India (2000) asserts that throughout Indian-held Kashmir, human rights violations are prevalent. In particular the report notes that it is widespread to have:

"Extrajudicial killings, including faked encounter killings, deaths of suspects in police custody . . . and excessive use of force by security

50 B Raman “Unrest in Gilgit-Baltistan” paper presented at a seminar on India's Himalayan Frontiers at the School of International Studies of the Jawaharlal Nehru University, New Delhi February $5^{\text {th }} 2005$. Available at $<$ http://www.saag.org/papers13/paper1241.html> accessed on December $17^{\text {th }}$ 2008.>

${ }^{51}$ R Knuth Burning Books and Leaving Libraries - Extremist Violence and Cultural Destruction (Westport: Praeger, 2006) p 77.

${ }^{52}$ Unreported World: Killing of Kashmir Channel 4 Documentary April $8^{\text {th }} 2004$.

53 CNN.com-Kashmir “Terror Group Warning” February 4 ${ }^{\text {th }} 2002$. [Available at: $<$ http://edition.cnn.com/2002/WORLD/asiapcf/south/02/04/india.kashmir/index.html $>$ Accessed 5 July 2005].

54 Public Commission on Human Rights State of Human Rights in Jammu and Kashmir 1990-2005 (New Delhi: Hindustan Printers, 2006) p 38.

${ }^{55}$ HRW Everyone Lives in Fear: Patterns of Impunity in Jammu and Kashmir Vol. 18 No 11(c) September 2006.

${ }^{56}$ HRW India: Abuse of the PSA in Jammu and Kashmir Amnesty International AI Index ASA 20/13/00 April 2000.

57 Physicians for Human Rights (UK), Kashmir 1991: Health Consequences of the Civil Unrest and the Police and Military Action (Dundee, 1991).

${ }^{58}$ S Kak Jashn-i-Azadi (Celebrating Freedom) Documentary on Kashmir 2007. 


\section{THE CREATION STORY OF KASHMIRI PEOPLE: THE RIGHT TO SELF-DETERMINATION}

forces combating active insurgencies, and torture and rape by police and other agents of the Government . . . arbitrary arrest and incommunicado detention in Jammu and Kashmir . . ."59

Unrelenting human rights abuses and the absence of safeguard mechanisms have been construed to indicate compromised law and order situations in Kashmir. The troops stationed in Kashmir have been given carte blanche authority to kill at sight, a practice backed up by the draconian laws. ${ }^{60}$ Under the Public Safety Act 1978 (as amended in 1990), a detainee may be held under administrative detention for a maximum of two years without a court order. Similarly, the Armed Forces (Special Powers) Act 1958 that was introduced in J\&K in December 1990 after declaring Kashmir and most of the Jammu province as disturbed areas gave the army unfettered powers to arrest people and thus reinforced impunity. Under s 3 of this act the army can arrest people without warrant and under s 4 (a) have power to shoot with intention to kill. The security force officials involved in committing human rights abuses generally enjoyed de facto impunity, although there were reports of investigations into individual abuse cases. ${ }^{61}$ In this context, the report of the US Department of State on Human Rights Practices for India (2000) further states:

"Problems have heightened in Kashmir, where judicial tolerance of the Government's heavy-handed counterinsurgency tactics, the refusal of security forces to obey court orders, and terrorist threats have disrupted the judicial system . . . the number of insurgency-related killings in Kashmir by regular Indian security forces has increased." 62

This lack of firm accountability has encouraged the security forces in establishing an environment in which human rights violations remain unpunished. Although India has numerous laws protecting human rights,

\footnotetext{
${ }^{59}$ US Department of State, Country Reports on Human Rights Practices- India 2000, Released by the Bureau of Democracy, Human Rights, and Labor February $23^{\text {rd }} 2001$. Available at <http://www.state.gov/g/drl/rls/hrrpt/2000/sa/717.htm> Accessed December $25^{\text {th }} 2008$.

${ }^{60}$ Jammu and Kashmir Armed Forces (Special Powers) Act 1990, the Prevention of Terrorism Act 2002, Jammu and Kashmir Public Safety Act 1978 and the Terrorist and Disruptive Activities (Prevention) Act 1987.

${ }^{61}$ US Department of State, Country Reports on Human Rights Practices-India 2005, Released by the Bureau of Democracy, Human Rights, and Labor March $8^{\text {th }} 2006$. Available at <http://www.state.gov/g/drl/rls/hrrpt/2005/61707.htm> Accessed on December $25^{\text {th }} 2008$.

${ }^{62}$ Above n 59.
} 
enforcement is lax and convictions very rare. ${ }^{63}$ In addition Kashmiris have also suffered human rights abuse by militant groups which include widespread torture, rape and other forms of violence including kidnapping and extortion. ${ }^{64}$ The perpetrators remain nameless and their crimes unrequited. Furthermore, frequent cross border firing at the LOC between the Indian and Pakistani armed forces has killed thousands of people living on both sides, forcing local populations to migrate. ${ }^{65}$

Over the years, Kashmir has also suffered economically as a result of unremitting violence. The devastating earthquake in the region surfaced an important clue that from the last 61 years no roads were built in this region, which literally put a halt to the rescue and relief operations there. This lack of basic infrastructure resulted in an increased death toll to more than 80,000 people which was a great catastrophe seen ironically against the investment of millions to maintain armies in this region. ${ }^{66}$ Asset stripping of Kashmir is commonplace and natural resources like water, power, forest products and minerals are exploited by India and Pakistan for their own uplift, rather than for the benefit of the people of Kashmir. ${ }^{67}$

\section{(b) Kashmiriyat - The Way of Life}

Despite the political turmoil and de facto division of Kashmir, the special cultural bond of Kashmiriyat unites the people. The ethos of Kashmiriyat is a thirteenth century principle that was spawned due to religious activities of the Shaivites $^{68}$ and Sufis ${ }^{69}$ in Kashmir. The Hindu and Muslim religions continued to flourish side by side and nourished the united culture of Kashmir. During this time a large part of the population in the Kashmir Valley converted to Islam after the preaching of Sufism impressed them. The Sufi saints came to Kashmir and among them the most famous Sheikh-Noor-

\footnotetext{
63 Ibid.

64 Ibid.

${ }^{65}$ N Khan "Human Rights Violations and Right of Self-Determination of Kashmiri People in the Light of Historical Facts." Available at <http://kashmir.ahrchk.net/mainfile.php/documents/14/> Accessed on December $17^{\text {th }}$ 2008.

${ }^{66}$ The Independent November $24^{\text {th }} 2005$ pp $1-2$.

67 J D Howley “Alive and Kicking: The Kashmir Dispute Forty Years Later” (1991) 9 Dickinson Journal of International Law 87 at 88-89.

${ }^{68}$ Also called Shaivism, Sivaite and Sivaism. It is a sect of Hinduism, exclusively devoted to the worship of the God Siva as the Supreme Being. See $<$ http://dictionary.oed.com/cgi/entry/> accessed on 30 ${ }^{\text {th }}$ March 2006.

69 Sufism is the mystical and spiritual system of the Sufis Islam. Sufis is a sect of Muslim ascetic mystics who embrace pantheistic views of Islam.
} 


\section{THE CREATION STORY OF KASHMIRI PEOPLE: THE RIGHT TO SELF-DETERMINATION}

ud-din $^{70}$ was revered by Kashmiri people (both Hindus and Muslims) as Nand Rishi. ${ }^{71}$ Sufism in Kashmir not only popularised Islam but also laid a humanist foundation for the cultural harmony. This resulted in an inherent openness in the Kashmiri culture that allows relative freedom of religion and philosophical beliefs. The influences of Hinduism (Shaivism) and Sufism made the Kashmiri identity truly distinct. The people of Kashmir therefore support mutual coexistence and universal brotherhood and that today could be translated as a concept akin to democracy, secularism, social justice, and

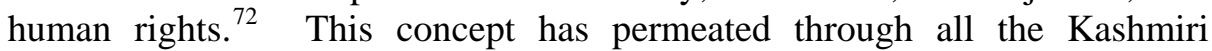
communities including Azad Kashmir, internally displaced Kashmiris, Kashmiri Diaspora ${ }^{73}$ and the Kashmiri Pundits who were forced to migrate to Jammu in $1990 .^{74}$ In fact a new form of Kashmiriyat has developed over time, which binds the displaced Kashmiri people in empathy with those who stayed back. For the last 61 years from across de facto borders and within Kashmiri diaspora, there has been a special bond associated with their sense of Kashmiriyat ${ }^{75}$ which gives them a sense of cohesion rather than division. It is this special bond that they truly cherish and desire to protect.

${ }^{70}$ A Tandon “The Need for Community Involvement in Preventing and Responding to Heritage Emergencies in Jammu and Kashmir.” Available at

$<$ http://icom.museum/disaster_preparedness_book/country/tandon.pdf > Accessed on March $30^{\text {th }} 2006$.

${ }^{71}$ The Kashmiri Pandits also call him Sahzanand. Kashmiri Hindus adapted to the way of life of Sufi Islam. For example Kashmiri Hindus were the only Saraswati Brahmins eating non-vegetarian dishes and would eat Halal meat so very peculiar to Muslims. See I Bakhshi "Where Shaivism meets Sufism.” Available at Kashmir Live <http://www.kashmirlive.com/kashmirlive/cult1.html> Accessed on March 31 2006.

72 R Paul "Reviving Ethics in Strife-Torn Kashmir", June 2005. Available at $<$ http://www.changemakers.net/journal/300506/paul.cfm> Accessed March 30 2006.

73 P Ellis and Z Khan "Kashmiri Displacement and the Impact on Kashmiriyat" (2003) 12(4) Contemporary South Asia 523 at 523.

74 See "Pandits Welcome, but No Homeland" Geelani Greater Kashmir, April 20 2006. Chairman of a hard-line faction of Hurriyat Conference, Syed Ali Shah Geelani addressing to the delegation of Hindu Welfare Society of Kashmir said the people of the Kashmir valley would welcome the return of Pandit migrants to their homes. He said, "People of Kashmir have launched their struggle against the Indian occupation and not against any religion or people of India. . . Hurriyat demands right to selfdetermination for the people of Jammu and Kashmir irrespective of cast, creed, colour or religion."

${ }^{75}$ N Ali, P Ellis and Z Khan "The 1990s: A Time to Separate British Punjabi \& British Kashmiri Identity” in G Singh \& I Talbot (eds) Punjabi Identity: Changes and Developments (New Delhi: Manohar, 1996); P Ellis and Z Khan "Diasporic Mobilisation and the Kashmir Issue in British Politics” (1998) 24 (3) Journal of Ethnic and Migration Studies 471. 


\section{GENESIS, MEANING \& DEFINITION OF “PEOPLES" WITHIN INTERNATIONAL LAW AND ITS APPLICABILITY TO KASHMIR}

In Europe towards the beginning of the seventeenth century, the authoritarian power and rule by the religious groups was diminishing and the concept of nations and international community was gaining ground. ${ }^{76}$ During this period the command of the sovereign was a source of sovereignty within the state. The fundamental goal of the principle of popular sovereignty was to transfer sovereignty from the ruler to the "peoples." Consequently, individual allegiance to the monarch passed to state. ${ }^{77}$ The American, French $^{78}$ and Bolshevik Revolutions became significant in shaping the modern form of the self-determination of peoples, which focused on the popular sovereignty. ${ }^{79}$ It was only after the First World War and Paris Peace Conference of $1919^{80}$ that the right to self-determination started to transform from the political principle to its present authoritative status in international law.

The meaning of "people" expanded with the need and choice of people within nation-states. During that time two significant theories of selfdetermination were used to define the people, which Koskenniemi describes as classical and romantic theory. ${ }^{81}$ According to the classical theory of selfdetermination people were essentially identified within territorial terms. For example during the French Revolution the uprising was seen taking place within the established territorial framework and state identity was determined only by nationality. On the other hand Germany utilised the romantic theory of self-determination in which German people are identified on the basis of a cultural group based upon a common history and language as the Volk. It became necessary because historical conditions obligated the united German nation to develop the German State.

\footnotetext{
${ }^{76}$ A Nussbaum A Concise History of Laws of Nations (New York: 1962) p 1.

$77 \mathrm{P}$ Radan Break-Up of Yugoslavia and International Law (London: Routledge, 2001) p 8.

${ }^{78}$ B Wells “United Nations Decisions on Self-Determination” (New York University, 1963) pp 1-14.

${ }^{79}$ T Frank "Post-Modern Tribalism and the Right to Secession" in C Brolmann, R Lefeber and M Zieck (eds) Peoples \& Minorities in International Law (Martinus Nijhoff Publishers, 1993) pp 3-27, especially p 6.

80 The Paris Peace Conference and the Treaty of Versailles: The Remaking of Europe in 1919. Available at <http://www.nv.cc.va.us/home/cevans/Versailles/Index.html> Accessed on April 14 2006.

81 The 'classical' and 'romantic' labeling of self-determination theories is adopted from M Koskenniemi “National Self-Determination Today: Problems of Legal Theory and Practice” (1994) 43 ICLQ 249.
} 


\section{THE CREATION STORY OF KASHMIRI PEOPLE: THE RIGHT TO SELF-DETERMINATION}

Keeping in view the history of Kashmir, Kashmiris can utilise both of these theories to describe them as people and become the legal aspirants of self-determination. Utilising the classical theory, Kashmiris at the time of decolonisation could be identified as a population which had a right to determine its future within the territorial limits. On the other hand, in employing the romantic theory, Kashmiris can rely on their ethnicity of Kashmiriyat to recognise them as a people, which has given them a sense of belonging to a specific group that has a common history and culture.

\section{(a) Decolonisation Definition: People within the Territorial Limits}

In the post-Second World War setting self-determination of peoples became most closely associated with decolonisation. During this time the concept of people was interpreted to mean total population inhabiting a territory occupied by a foreign power. The legal basis to claim selfdetermination stemmed from brief suggestions to the "principle of equal rights and self-determination of peoples" in Arts 1(2) and 55 of the UNC. Art 1(2) declared that one of the purposes of the UNC is:

"To develop friendly relations among nations based on respect for the principle of equal rights and self-determination of peoples, and to take other appropriate measures to strengthen universal peace." ${ }^{\text {2 }}$

During the decolonisation period there was a lot of confusion as to the exact contours of the description of "people." In 1951, Kelsen defined "people" by equating people to "State" and concluded that peoples in the same clause meant states. ${ }^{83}$ However, the travaux preparatoires to the UNC reveals that drafters never intended the term "people" to denote states. The committee expressly made it clear that Art 1(2) "extends to States, nations and peoples". ${ }^{84}$ The decolonisation definition of "people" also appears in the resolution 1514(XV) which focuses on the maintenance of the territorial integrity in the non-self-governing ${ }^{85}$ territories (NSGT). This resolution corresponds with the international principles of territorial integrity, the inviolability of State borders, sovereignty and uti possidetis. ${ }^{86}$ The principle

\footnotetext{
${ }^{82}$ B Simma (ed) The Charter of the United Nations - A Commentary (Oxford: Oxford University Press, 1994) p 49.

${ }^{83} \mathrm{H}$ Kelsen The Law of the United Nations: A Critical Analysis of its Fundamental Problems (London: Stevens, 1951) p 52.

${ }^{84}$ (1945) 6 UNCIO 704.

${ }^{85}$ UNGA Res. 1514 (XV) (December $\left.14^{\text {th }} 1960\right)$ para [6].

${ }^{86}$ S Ratner "Drawing a Better Line: Uti Possidetis and the Borders of the New States" (1996) 90 AJIL 590.
} 
of uti possidetis started off as a Roman law concept regulating private property, especially possession. If possession of a property was achieved in good faith and not by the use of force or any fraudulent means, Roman magistrates applied the famous rule of ita possideatis ie "as you possess, so you may possess." 87 This concept gradually entered into the realm of international law defining sovereign rights over State territory and borders of newly formed States on the basis of their previous administrative frontiers. ${ }^{88}$ During the end of the Second World War and process of decolonisation, the territorial delimitation of new states was based on uti possidetis, which was meant to coincide with their national frontiers with the former colonial borders. ${ }^{89}$ In Sovereignty over Certain Frontier Land ${ }^{90}$, two Latin American judges - Armand-Ugon and Moreno Quintana of the ICJ held that the practice of uti possidetis had crystallised into the general principle of law.

Using the uti possidetis principle during the decolonisation process, people were defined within the territorial borders of NSGT and no consideration was given to their disparate culture, religion or language. It was believed that these people through the process of nation building would overcome these differences. ${ }^{91}$ Therefore, the UN became very much averse to permit partition of NSGT, irrespective of their diverse constituent ethnic minorities or religious groups. For this reason the GA approved the transfer of West Irian by the Netherlands to Indonesia even though the population of West Irian differed significantly from that of Indonesia in terms of race, ethnicity, language and culture. The GA endorsed the arguments of Indonesia that such differences are irrelevant, given the fact that West Irian had been a part of the NSGT under the Netherlands East Indies. ${ }^{92}$ Likewise, the SC took action to stop the partition of Cyprus into two political entities despite the fact that there was a deep-rooted tension between Greek and Turkish Cypriots. ${ }^{93}$

${ }^{87}$ W Reisman "Protecting Indigenous Rights in International Adjudication” (April 1995) 89 (2) AJIL 352 footnotes 8 and 9.

${ }^{88}$ E Hasani "Uti Possidetis Juris: From Rome to Kosovo" (2003) 27 Fletcher Forum of World Affairs 85 at 86.

${ }^{89}$ Ibid, at 87.

${ }^{90}$ [1959] ICJ Rep 240 \& 255.

91 J Humphrey "Preventing Discrimination and Positive Protection for Minorities: Aspects of International Law” (1986) 27 Cahiers de Droit 23 at 25.

92 GA Res. 1752 (XVII) (September 21 $1^{\text {st }}$ 1962). Similarly, the GA Resolutions 2230 (XXI) of December 20 1966 and 2355 (XXII) of December $19^{\text {th }} 1967$ were moved to ensure the continued union of the Rio Muni and the island of Fernando Po which together constitute Equatorial Guinea.

${ }^{93}$ SC Res. 541 (November 18 ${ }^{\text {th }}$ 1983); J Maguire "The Decolonisation of Belize: SelfDetermination vs Territorial Integrity” (1982) 22 Virginia Journal of International Law 849 at 864. 


\section{THE CREATION STORY OF KASHMIRI PEOPLE: THE RIGHT TO SELF-DETERMINATION}

Recollecting the history of Kashmir, Kashmiris emerged as people within the decolonisation definition of self-determination. Under the decolonisation definition of self-determination people of Kashmir can therefore be described as "an organic whole population within pre-1947 territorial limits." Keeping in view the uti possidetis principle and decolonisation definition of people, it is arguable that the subsequent de facto divisions of the territory of Kashmir between India, Pakistan and China were legally invalid. For the purposes of nation building Kashmiris could therefore be classified as people within Art 1(2) of UNC as a nation. This argument is also validated by the fact that British India and the UN recognised Kashmiris as a people. ${ }^{94}$ At the time of the decolonisation of the Indian subcontinent, the British identified Kashmir as a territory and the Kashmiris as a people by giving them the choice to remain independent in pre-1947 colonial borders under the Cabinet Mission Memorandum, 1946. On the other hand, the UN identified Kashmiris as a people by letting them determine their future through a plebiscite in the postcolonial era, and as discussed, the same was put in place by the SCRs.

\section{(b) Non-Representative Government: People outside Territorial Limits}

With the expanding scope of right to self-determination, it became increasingly difficult to restrict the meaning of "people" to colonial or dependent peoples. Para 7 of Resolution 2625 (XXV) declared that:

"Nothing in the foregoing paragraphs shall be construed as authorizing or encouraging any action which would dismember or impair . . . the territorial integrity of independent States conducting themselves in compliance with the principle of equal rights and selfdetermination of peoples . . . thus possessed of a government representing the whole people belonging to territory without distinction as to race, creed or colour". ${ }^{95}$

This paragraph has been understood to mean that protection of territorial integrity of a sovereign State is conditional to the existence of the representative government. ${ }^{96}$ The right to self-determination can therefore be claimed by the people in many situations including in "cases in which the Government of a State is unrepresentative of its peoples by virtue of the fact

\footnotetext{
${ }^{94}$ SC Resolution adopted by UNCIP August $13^{\text {th }} 1948$ Part II B (1); SC Resolution adopted by UNCIP, January $5^{\text {th }} 1949$, para [1].

${ }^{95}$ GA Res. 2625 (XXV) October $24^{\text {th }} 1970$.

96 M Pomerance Self-Determination in Law and Practice (The Hague: Martinus Nijhoff, 1982) p 39.
} 
that it excludes a distinct group from equal participation in political life". ${ }^{97}$ Embodying the unrepresentative government definition of people the Helsinki Declaration ${ }^{98}$ affirms:

"All peoples always have the right ... to determine, when and as they wish, their internal and external political status, without external interference, and to pursue as they wish their political, economic, social and cultural development."

Hence, in the post-colonial era a possibility is generated to define the people outside territorial integrity if they are discriminated against by their own government on the basis of their culture, religion and ethnicity. However, this enthusiasm to extend the definition of people outside the traditional system is ridiculed to avoid secession. This statement can be affirmed by the comments of Pomerance, ${ }^{100}$ Hannum $^{101}$ and Cassese. ${ }^{102}$ These authors maintain the limited scope of Resolution 2625 (XXV) by pointing out that secession is only justifiable if the state government underrepresents its peoples. On the other hand, Buchheit visualises it as part of a broader perspective based on the premise that oppression legitimises secession. He believed that international law recognises a continuum of remedies ranging from protection of individual rights to minority rights, and ending with the secession as an ultimate remedy. ${ }^{103}$ In other words oppressed people living under a non-representative government could qualify as people for the purposes of self-determination.

In the aftermath of an impromptu but welcoming end to autocratic rule in 1947, people in IAK were forced to live under non-representative regimes nominated by India. ${ }^{104}$ The successive nominated governments were pressed

97 Saskatoon Recommendation on Self-Determination, World Conference on Human Rights, 1993. This recommendation refers to right to self-determination as a continuous right, it can be used to avoid or remedy the human rights abuses and it can entitle a particular population the right to secede.

98 (1975) 14 ILM 1292. This Declaration is also known as Final Act of the Conference on Security and Cooperation in Europe (CSCE).

${ }^{99}$ Above n 96.

100 Ibid.

$101 \mathrm{H}$ Hannum Autonomy, Sovereignty and Self-Determination (Philadelphia: University of Pennsylvania Press, 1990) p 473.

102 A Cassese "Political Self-Determination: Old Concepts and New Developments" in A Cassese (ed) UN Law/Fundamental Rights (Netherlands: Alphen aan den Rijn, Sijthoff \& Noordhoff, 1979) p 145.

${ }^{103}$ L Buchheit Secession (New Haven: Yale University Press, 1978) p 222.

${ }^{104}$ Above n 5. India integrated Kashmir into its constitution unlike Pakistan which believes the final disposition of Kashmir will be decided by a UN held plebiscite. 


\section{THE CREATION STORY OF KASHMIRI PEOPLE: THE RIGHT TO SELF-DETERMINATION}

to frame laws in order to integrate Kashmir into the Union of India. The incorporation process was carried out while ignoring the SCR 91(1951) and 122 (1957), which affirmed that any action taken by the State Assembly will not change the final disposition of the Kashmir dispute. The New Constitution of Jammu and Kashmir 1957 was adopted in contravention of the SCRs and does not respect the fundamental rights of the people of Kashmir. The fundamental rights in the Constitution of India 1950 are extended to Kashmir with unacceptable modifications. The curtailment of Art 19 (Right to Freedom) in Kashmir for example violates their right to peaceful assembly, form associations or unions and move freely. ${ }^{105}$ The Judiciary in Kashmir cannot guarantee this right like the other High Courts in India can. ${ }^{106}$ In this context, Anand states that "it is hoped that when normal conditions are restored these curtailments on the rights of Kashmiri people will be removed.” ${ }^{107}$ Likewise, Kashmiri Muslims are an exception to the National Commission for Minorities Act 1992 (NCM), ${ }^{108}$ despite the fact this legislation enumerates five religious communities including Muslims as a minority within India. At present Kashmiri Muslims comprise only 2 percent of the 13.80 percent Muslim population within India ${ }^{109}$ which should warrant them the minority status within India. On the other hand the people in PAK are economically deprived, which became evident during the earthquake of 2005. For the purposes of Resolution 2625 it is arguable that the nonrepresentative government in Kashmir sustains the self-determination argument in the post-colonial era.

\section{(c) Human Rights Violation - Link to Self-Determination}

The meaning of the term "people" during the decolonisation era from late 1940s through 1960s was predominantly seen as the population of a defined territorial unit. However, during this era a parallel view emerged that the concept of "people" may be defined in reference to other criteria such as the presence of human rights violations. This link was established in 1950 when GA recognised the right to self-determination as a fundamental human

\footnotetext{
${ }^{105}$ Art 19 of the Constitution of India 1950.

106 A Anand The Constitution of Jammu \& Kashmir-Its Development \& Comments (New Delhi: Universal Law Publishing Co Pvt Ltd, 4th edn, 2004) p 166.

107 Ibid.

108 The Act (XIX of 1992) was passed on May $17^{\text {th }} 1992$ and was enforced with effect from May $17^{\text {th }}$ 1993. It was amended by the National Commission for Minorities (Amendment) Act 1995 passed on September $8^{\text {th }} 1995$ for creating the post of ViceChairman.

109 See <http://en.wikipedia.org/wiki/Demographics_of_Islam> Accessed January $6^{\text {th }}$ 2007.
} 
right. ${ }^{110}$ In Resolution 545(VI) of 1952, GA decided that the international covenant on human rights should include the right of all peoples and nations to self-determination. ${ }^{111}$ This approach was taken at a time when the ethnic differences started to threaten the future stability of the colonies. For example, the division of Palestine into Jewish and Arab States ${ }^{112}$ was justified on this basis. Keeping up with this thought the World Conference on Human Rights underlined the importance of an effective realisation of the right to self-determination by considering its denial as a violation of human rights. ${ }^{113}$

In the debate over definition of "peoples", self-determination surfaced as the "fundamental human right". The common Art 1 of the International Covenant on Civil and Political Rights (ICCPR) ${ }^{114}$ and the International Covenant on Economic, Social, and Cultural Rights (ICESCR) ${ }^{115}$ included the right of self-determination for peoples. Art 1(1) of both human rights covenants provides that all peoples have the right to self-determination and by virtue of this right they can freely determine their political status and freely pursue their economic, social and cultural development. This right encourages people to choose their political status in the post-colonial world. The right to self-determination, which includes economic self-determination, has been clearly established as a right in international law and forms a part of the norms of jus cogens. ${ }^{116}$ Consequently, the right to self-determination of peoples as provided for in the covenants is therefore a continuing right and a permanent one. ${ }^{117}$ Art 1(2) of these two covenants provides that people of a

${ }^{110}$ UNGA Res. 421 (V) (December $4^{\text {th }} 1950$ ) para [6].

${ }^{111}$ UNGA Resolution 545 (VI) (February $5^{\text {th }}$ 1952) para [1].

112 Resolution 181 (II) (November 29 $9^{\text {th }}$ 1947). The resolution 181 (II) approved with minor changes the Plan of Partition with Economic Union as proposed by the majority in the Special Committee on Palestine. The partition plan attached to the resolution provided for the termination of the Mandate, the progressive withdrawal of British armed forces and the delineation of boundaries between the two States and Jerusalem. However, the adoption of Resolution 181 (II) was followed by outbreaks of violence in Palestine.

113 World Conference on Human Rights: Vienna Declaration and Programme of Action 1993 (Vienna, June 14-25 ${ }^{\text {th }}$ ) A/CONF.157/23, July $12^{\text {th }} 1993$, para [2]).

114 International Covenant on Civil and Political Rights adopted at New York, December $16^{\text {th }} 1966$ and entered into force on March $23^{\text {rd }} 1976$ UNGAOR 2200A (XXI) 999 UNTS 171.

${ }^{115}$ International Covenant on Economic, Social and Cultural Rights, adopted at New York $16^{\text {th }}$ Dec. 1966 and entered into force on January $3^{\text {rd }} 1976$. UN GAOR, 2200A (XXI), 993 UNTS 3; Article 20 (1) of AFCHPR refers to "the inalienable right to selfdetermination of all peoples.”

116 J Rehman International Human Rights Law - A Practical Approach (Longman, 2003) p 109.

117 Comment made by the Chairman of the Working Party of the Third Committee when presenting the Draft to the Third Committee UN Doc. A/C.3/SR. 668 para [3]. 


\section{THE CREATION STORY OF KASHMIRI PEOPLE: THE RIGHT TO SELF-DETERMINATION}

sovereign state have the right to utilise their natural wealth and resources for their own requirements and the governments chosen are expected to exploit natural territorial resources for the profit of people living there. Similarly, Art 1(3) of these covenants guarantees the people of dependent territories (nonself-governing \& trust territories) the right to decide their international status.

India has reserved common Art 1 of these covenants, arguing that the right to self-determination does not directly affect an independent state because it applies to people under foreign domination and not to people of sovereign independent states or to a section of people in a nation, which is the essence of national integrity. ${ }^{118}$ However, France, the Federal Republic of Germany and the Netherlands objected to the reservation on the grounds that the right to self-determination applies to all peoples. ${ }^{119}$ In Reference Re Secession, the Supreme Court of Canada favoured self-determination as a human right. ${ }^{120}$ Consequently, it is evident from both the textual analysis of major international instruments and from a review of UN practice that the term "people" cannot be limited to the population of NSGT. The purpose of the development of the right to self-determination was part of the international community's vigorous attempts to eradicate the oppression of individuals and the groups by the states. ${ }^{121}$ Subsequently, if the need arose, people could be identified outside the territorial limits as human rights violation victims.

In view of this discussion, it is clear that the people of Kashmir can be classified as human rights victims who are under reprehensible regimes. In IAK, India is committing gross human rights violations to suppress the claim for the right to self-determination. ${ }^{122}$ It is arguable that such a violent behaviour also qualifies as aggression. The definition of aggression does not prejudice the right to self-determination of peoples who are forcibly deprived of this right and particularly so if they are under an alien domination. ${ }^{123}$ Likewise, the people of PAK are victims of economic violence and oppression and can succeed as people for the purposes of the right to self-determination.

118 For the text of the reservation, see UN Human Rights, Status of International Instruments UN Doc. ST/ HR/5 1987 p 9; Multilateral Treaties Deposited with the Secretary General: Status as at 31st December 1994 (New York: United Nations, 1995) 109. India's ratified ICCPR on April $10^{\text {th }} 1979$.

${ }^{119}$ UN Human Rights, Status of International Instruments (1987) UN Doc. ST/ HR/5, 18.

120161 DLR (1998) 385, 437. The Court in this case also showed the inclination towards the ethnic definition of "peoples".

${ }^{121}$ Art 4, Vienna Declaration and the Programme of Action arising from the United Nations World Conference on Human Rights in 1993; M Riesman "Sovereignty and Human Rights in Contemporary International Law” (1990) 82 AJIL 866.

${ }^{122}$ T McGirk “Kashmiri Student Tells of Torture” The Independent May 25 1993.

${ }^{123}$ Art 7 of Res 3314 (XXIX) $2319^{\text {th }}$ Meeting December $14^{\text {th }} 1974$. 


\section{(d) Ethnic and Minority Groups \& Definition of 'Peoples'}

In the post-colonial era up to the 1970s, GA continued to refer to certain specific ethnic groups as "peoples" like the people of Bangladesh. ${ }^{124}$ The majority of East Pakistan was a Bengali speaking ethnic minority group and was able to separate from West Pakistan and form a new nation. This constitutes the implicit recognition of ethnic groups as peoples who share a common culture, language, religion, ideology, geography and territory. During the nineteenth century ethnic affinity has been defined by the concepts of nation, nationality or nationalism. As far as the definition of these terms is concerned no single definition was approved and each definition had significant exceptions attached to it. ${ }^{125}$ However, the ethnic and minority definition has a common similarity of reliance on both an objective and subjective level. In other words it meant that ethnic groups are not only to be identified as people but these acknowledged groups should also demonstrate the subjective element of awareness to preserve their distinct identity. The ethnicity has played a crucial role in most of the contemporary armed conflicts and political struggles around the world. ${ }^{126}$

Under this definition it is submitted that Kashmiris share a common culture that transcends their religious and linguistic diversity. It is the common ethos of Kashmiriyat that unites the people of Kashmir. As a part of India and Pakistan, Kashmiris are a minuscule minority very much delineated from the people of both countries. It is particularly so because Kashmiris have maintained their cultural identity of Kashmiriyat as a distinct group and could be pictured as people in their own right. Hence, Kashmiriyat like Han Chinese monolithic civilization ${ }^{127}$ exerts a powerful and unifying influence on Kashmiri people producing cultural unity among them. Within the terms of definition offered by the United Nations Educational, Scientific and Cultural Organization (UNESCO) 1989, Kashmiris also qualify as a people. According to this definition, a group of individuals apart from having some elements in common like history or culture should "have the 'will' to be

\footnotetext{
124 Bangladesh on September $17^{\text {th }} 1974$ by GA resolution 3203 (XXIX) was recognized as UN Member State.

${ }^{125}$ A Cobban The Nation-State and National Self-Determination (New York: Thomas Y. Crowell, 1969) p 107.

126 S Lawson "Self-Determination as Ethnocracy: Perspectives for the South Pacific" in Mortimer Sellers (ed) The New World Order (Oxford: Berg, 1996) pp 153-174 at p 153.

${ }^{127}$ Y Fung A Short History of Chinese Philosophy (London: Collier-Macmillan, 1948) p 181.
} 


\section{THE CREATION STORY OF KASHMIRI PEOPLE: THE RIGHT TO SELF-DETERMINATION}

identified as a people or the consciousness of being a people.”128 The people of Kashmir not only have a common culture but also have zeal to protect it, which is clear by the fact that they have kept the Kashmir issue alive over the last 61 years.

\section{SUMMARY: SOME CORE PRINCIPLES}

From the previous discussion of peoples it became clear that with the changing trend, the UN has not limited the use of the term "people" to colonial people but recognised the right to self-determination of many noncolonial peoples including the people of South Africa and Palestine. ${ }^{129}$ This fact is corroborated by the ICJ ruling in Western Sahara, where the Court after referring to the key provisions of the Resolution 1514(XV), 1541(XV) and $2625(\mathrm{XXV})$ concluded that it was necessary in the process of selfdetermination, "to pay regard to the freely expressed will of the peoples." 130 Therefore, international law affords primacy to people and their rights flow from that position. ${ }^{131}$ As discussed, the definition of people in context to right to self-determination depends on the choice and circumstances of the population. For example, French people defined themselves within territorial limits, German people used their common history to identify themselves, Bangladeshis were identified as the human rights violation victims and Quebecers described themselves on the basis of common language. In the panorama of identity the approach of defining people can take varying forms. ${ }^{132}$ Accordingly, it could be inferred that choice is important for the people to determine how they wish to define themselves. It is arguable given the choice the people of Kashmir could define themselves both in the decolonisation and post-decolonisation period as "people" for the purposes of exercising the right to self-determination.

${ }^{128}$ UNESCO, International Meeting of Experts on Further Study of the Concept of the Rights of Peoples: Final Report and Recommendations, UNESCO doc. SHS89/CONF.602/7 at para [7-8].

${ }^{129}$ Res. 2396 (XXII) of December $2^{\text {nd }} 1968$ and 2672C (XXV) of December $8^{\text {th }} 1970$ respectively.

${ }^{130}$ Western Sahara [1975] ICJ Rep 33.

${ }^{131}$ Crawford rightly observed that "[f]rom the perspective of international law, the key feature of the phrase rights of peoples' is not the term 'rights', but the term 'peoples.'” See J Crawford “The Rights of Peoples: 'Peoples' or 'Governments?'” in J Crawford (ed) The Rights of Peoples (Oxford: Clarendon Press, 1988) p 55.

132 ILO Convention 107, 1957; ILO Convention 169, 72 ILO Bulletin 59 (1989); The WGIP draft declaration 1994 (UN doc. E/CN.4/1995/2, E/CN.4/sub.2/1994/56), p.105; M Lam At the Edge of the State: Indigenous People and Self-determination (New York: Transnational Publishers, 2000) pp 42-49. 
In the contemporary world the $19^{\text {th }}$ century nationalist ideal of one people, one nation, one state no longer seems possible or desirable. In current times the objective description of common ethnic, cultural, religious or other characteristics has no significance alone; it must be coupled with the subjective chosen connection of the people to identify them. The meaning of the right to self-determination depends on the introspective perception of the notion of "people." Consequently, the concept of the people is no longer understood as being entirely tied to sovereignty, nor to formal citizenship. Today, the right to self-determination of peoples has substantive and identitycentred content. The description of people has moved away from the debate over decolonisation and has broadened out to include various groups that possess common ties or share diversity. For the people of Kashmir, Kashmiriyat adds to their precise identity as people where diverse religion has no meaning within their culture. In the words of Salman Rushdie:

"The words Hindu and Muslim had no place in their story . . . in the valley [Kashmir] these words were merely descriptions, not divisions. The frontiers between the words, their hard edges, have grown smudged and blurred." 133

In consideration of factors that influence the political life of Kashmiris and the discussion of people in this discourse, this critique defines the "people of Kashmir" as: an organic whole population within the pre-1947 territorial borders of the State of Jammu and Kashmir that shares a distinct culture of Kashmiriyat and is now divided between three countries (namely India, Pakistan and China) and displaced in the aftermath of the war of 1947-48 and insurrection that followed since 1989, and whose population has suffered a political and economic breakdown; destruction of Kashmiriyat and gross human rights violations under the unrepresentative governments. This definition allows the people of Kashmir to exercise their right to selfdetermination.

\section{CONCLUSION}

The right to self-determination is construed as controversial and is usually understood by the international community as a means of disintegrating the state rather than a means of inclusion. However, this right has been argued as a peremptory norm ${ }^{134}$ within international law and an "essential condition for

133 S Rushdie Shalimar the Clown (New York: Random House, 2005) p 57.

134 "A norm accepted and recognised by the international community of States as a whole from which no derogation is permitted”. See Art 53 of the Vienna Convention 


\section{THE CREATION STORY OF KASHMIRI PEOPLE: THE RIGHT TO SELF-DETERMINATION}

the effective guarantee and observance of individual human rights.”135 Tracing the progress of the definition of "people" it was observed that during the First World War people were mostly described in terms of territoriality. This tradition was kept during the decolonisation era and people were strictly described as a population within a distinct territorial unit. Since the late 1960s it became increasingly anachronistic to restrict the meaning of people within the territorial borders and a view started to emerge that people may be identified with reference to linguistic, religious, cultural, ethnic identities and other affiliations.

Against these modern developments in the definition of "people" this discourse proposes that Kashmiris could be identified as a people for the purposes of exercising the right to self-determination. It was demonstrated that Kashmir was recognised as a unit of self-determination both by the British India and the UN. The former provided Kashmiris a chance to form an independent state and the latter through SCRs addressed the scope of the right to self-determination by offering the people of Kashmir an impartial plebiscite to determine their future. Since 1947, Kashmir was incorporated by India into its union in violation of SCRs 91(1951) and 122(1957) and in doing so people were never consulted.

From 1989 the people of IAK were unable to find a democratic outlet for expressing their grievances against the political non-representation, corruption and alienation, which led to an insurgency to claim their UN promised right to self-determination. This resulted in en masse clashes between the Kashmiri people and government forces resulting in human right violations such as extrajudicial killings, disappearances, torture and fake encounters. Today, the reservation of the right of self-determination by India has far-reaching implications especially in unabated human rights abuses in Kashmir which is evident from the US State Department report on India. ${ }^{136}$ The consecutive Indian nominated governments in Kashmir committed a series of errors that resulted in the isolation of the Kashmiris. Noorani, former advocate of Supreme Court of India, says:

"India's record shows lapses on five accounts - rigged elections, failure to respect the State's autonomy, corruption, discriminatory employment practices and failure to respect human rights.”137

on the Law of Treaties, adopted May $23^{\text {rd }} 1969$, came into force January $27^{\text {th }} 1980$ 1155 UNTS 331.

${ }^{135}$ General Comment No. 12: The Right to Self-Determination of People (Article 1): $13 / 03 / 84$ March $13^{\text {th }} 1984$, para [1].

136 Above n 59.

${ }^{137}$ Above $n 5$. 
On the other hand the Kashmiris in PAK are suffering massive economic human rights violations.

In paraphrasing the right to self-determination ascription to the people of Kashmir, their entitlement comes robust against the defence proffered by Indian and Pakistani governments to provide legal justification to deny this right both within international law and international practice. This is because the people of Kashmir under unrepresentative governments are suffering from human rights violations, political instability, economic deprivation, marginalisation and alienation. Internationally all of these factors are important pointers in the identification of units and groups as "people" for the purposes of self-determination. Relying on this background, it became clear that a prospect is generated whereby ethnically united Kashmiri people emerge as oppressed people, divided within the de facto borders and suffering human rights violations. This definition entirely synchronises with nonexhaustive modern definitions of "people" for the purposes of the right to selfdetermination. In order to exercise this right there is a vortex of world opinion behind the SCRs for a plebiscite to offer Kashmiri people the choice of how their future may unfold for them. 